\title{
MEDICO-LEGAL CONSIDERATIONS FOR
}

\section{MOREL-LAVALLÉE LESIONS}

Authors:

Quentin SCANVION, Erwan LE GARFF, Didier GOSSET, Valéry HEDOUIN, Vadim MESLI.

\section{Author affiliations:}

CHU Lille, Institut de Médecine Légale, EA 7367 UTML - Unité de Taphonomie MédicoLégale, Univ.Lille, F-59000 LILLE, France.

Corresponding author:

Quentin SCANVION

ORCID:

Quentin Scanvion: 0000-0001-5865-1525

Erwan Le Garff: 0000-0003-0416-4427

Valéry Hédouin: 0000-0002-0461-1189

Vadim Mesli: 0000-0003-0309-3356

\section{Keywords:}

Morel-Lavallée, forensic medicine, subcutaneous tissue lesion, accidents.

Article type: Case report

Compliance with ethical standards

Conflict of interest: The authors declare that they have no conflict of interest. 
Funding: none

Ethical approval: Approval by Ethical Committee is not required for case reports as single case descriptions do not fulfil the criteria of research as defined by the Human Research Act. Patient information has been withheld to protect patient anonymity. 


\section{MEDICO-LEGAL CONSIDERATIONS FOR}

\section{MOREL-LAVALLÉE LESIONS}

\section{Abstract}

The Morel-Lavallée lesion is an infrequent traumatic lesion that the forensic physician may need to evaluate during examination of a victim. Using a review of the literature and an illustrative case, the objective is to discuss the medico-legal issues (accountability, functional recovery and healing times, and aftermath) associated with Morel-Lavallée lesions. We describe the case of a 24-year-old motorcycle driver who was hit by a car. Clinically, the right lumbar region had a large $16 \times 15 \mathrm{~cm}$ ecchymosis with subcutaneous fluid swelling found by palpation. A body scan revealed a Morel-Lavallée lesion among other lesions. On day 7, its thickness was decreased by half. Morel-Lavallée lesions are specifically induced by shearing force with moderate-to-high kinetics in an anatomical area with an underlying fascia. The associated functional disability is globally moderate, but a large lesion or recurrences can extend the time needed to recover. Apart from some exceptions, care without any delay in diagnosis and treatment allows evolution of the lesion without functional consequences, but these lesions are frequently unnoticed in the initial phase.

\section{Key points}

- The Morel-Lavallée lesion is an infrequent lesion, often missed in the initial phase, but should be known for medico-legal reports.

- The Morel-Lavallée lesions are the result of a shearing force causing translational movement.

- Road crashes are the main cause of Morel-Lavallée lesions and sports requiring sliding actions rank second in order of frequency.

- Its functional disability is globally moderate, but a large lesion or recurrences can increase the time of resolution of the disability. 


\section{Introduction}

The Morel-Lavallée lesion (MLL), also called closed degloving injuries, is an infrequent traumatic lesion $[1,2]$ that the forensic physician may need to consider during examination of a victim.

The pathophysiology of this lesion is specific to its mechanism. MLLs are the result of a shearing force causes translational movement of the dermis against the fixed plane of the underlying muscular fascia. The perforating lymphatics and blood vessels in that area are disrupted and a haematoma/seroma can arise $[3,4]$.

From a review of the literature, and as illustrated by a case, the objective is to discuss the medico-legal issues of the MLL, including (i) its accountability, (ii) its functional recovery and healing times, and (iii) its permanent aftermath.

\section{Case report}

A 24-year-old motorcycle driver was hit by a car, which was coming perpendicularly to his right side. He lost consciousness at impact and reported loss of memory of the incident. The accident mechanism and kinetics thus could not be described. Clinically, the right lumbar region of the patient had a $16 \times 15 \mathrm{~cm}$ ecchymosis with subcutaneous fluid swelling that could be sensed. In the emergency department, a body scan revealed a moderate right pneumothorax with a pneumatocele of the right lower lobe; a displaced fracture of the middle arch of the ninth right rib with adjoining parietal emphysema; a grade III right renal fracture (depth $>1 \mathrm{~cm}$, with perirenal haematoma, no urinoma); a grade II hepatic fracture (segments VII and VI); a $74 \times 15 \times 72 \mathrm{~mm}$ fluid and haematic swelling of the subcutaneous tissues in the right lumbar region, compatible with a MLL (Fig. 1); and a left L5-S1 disc herniation without any traumatic bone lesions of the spine and pelvis. Close clinical monitoring was implemented because of the deep organic lesions. The control CT scan at day 7 showed regression of all thoracic and renal lesions, a stable hepatic fracture and regression from $15 \mathrm{~mm}$ to $8 \mathrm{~mm}$ thickness of the MLL. Six months later, all lesions had completely disappeared on another CT scan. 


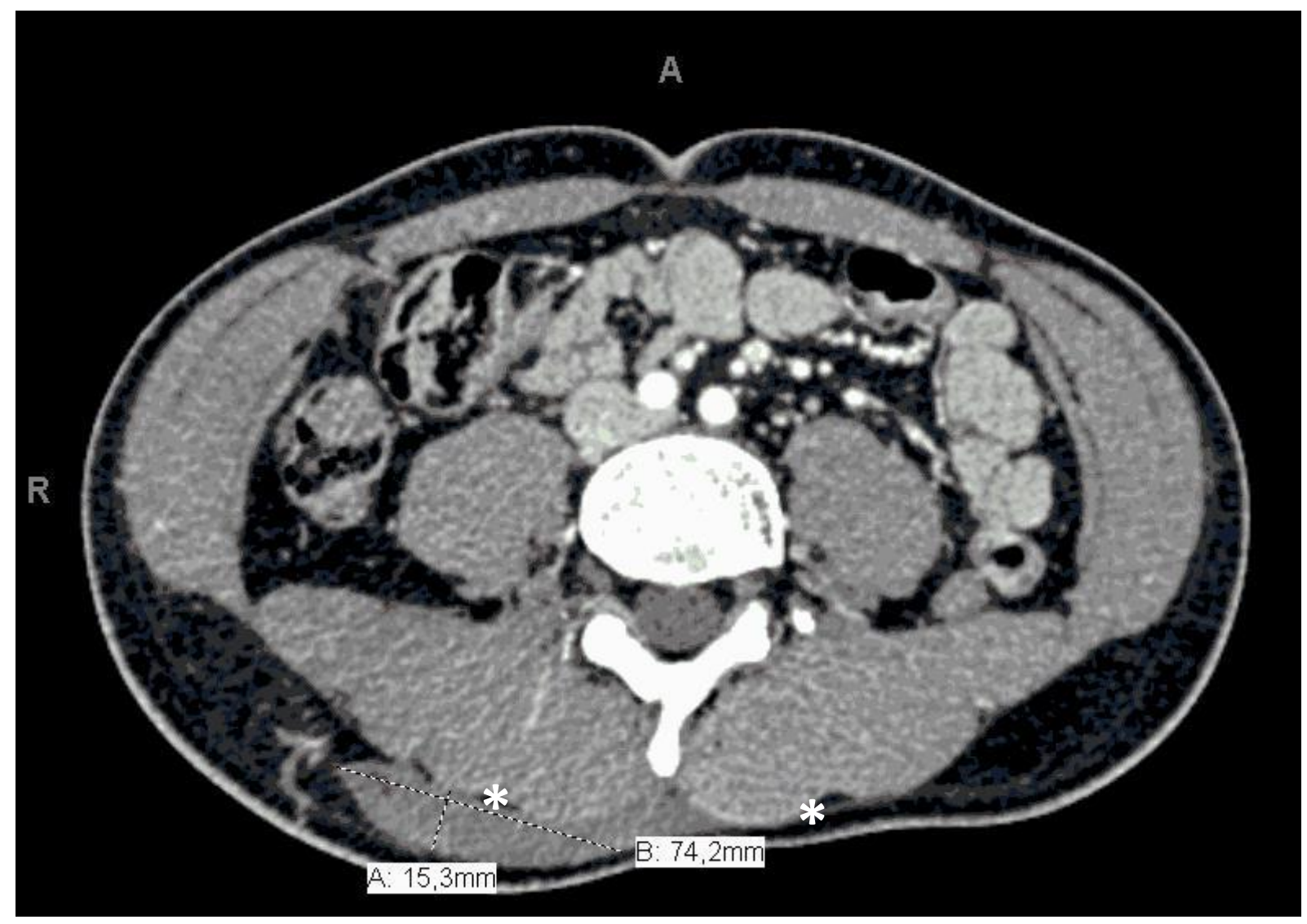

Fig. 1: Right lumbar Morel-Lavallée lesion (CT scan at the height of the fourth lumbar vertebra). $A=$ thickness of the lesion; $B=$ width of the lesion; ${ }^{*}=$ posterior layer of the thoracolumbar fascia.

\section{Discussion}

\section{Morel-Lavallée lesion and accountability}

This subcutaneous fluid mass is the result of tangential forces, shearing, rubbing or crushing injuries [1] with moderate to high kinetics $[1,3]$ in an anatomical area with an underlying fascia. The most common areas affected are the great trochanters, buttocks, thighs, knees and lumbar spine $[3,5]$. In our clinical case, the MLL is more likely related to tangential impact of the hood of the car than rubbing after projection on the road. Indeed, the examination found a large bruise without any excoriation of the lumbar region. Symptoms may appear with mild to moderate latency after trauma. Thus, in the literature, a median diagnosis time of 2 weeks has been described (from a few hours to several months) $[1,6]$. Scolaro et al. [7] also estimate that a significant number of patients have a missed or delayed diagnosis because of distracting injuries in the polytraumatized or delayed superficial 
discolorations of the skin. Road crashes are the main cause of MLLs [1,5]. Sports requiring sliding actions (such as football, soccer, or baseball) rank second in order of frequency $[8,9]$. Mellado and Bencardino [10] published a chronological classification based on the MRI characteristics of MLLs [3] (Table 1). In the case of a recent trauma, the presence of a fibrous capsule is the sign of a chronic lesion and would suggest a previous state of health. However, an MRI is not systematically performed in a forensic context or in the case of a road crash (a body scan is performed instead). However, an ultrasound or scan can show a capsule surrounding the collection superficial in the muscular layer and deep in the hypodermis. In the case of chronic post-traumatic pain, an MRI (the gold standard [10]) may be recommended to confirm the diagnosis and to obtain more information about the age of the lesion, which is necessary to determine accountability. In the context of forensic expertise, reassessment would be necessary a few months later (i) in case of uncertain clinical diagnosis or (ii) to know the evolution when the lesion is large. During an autopsy in postmortem cases, the discovery of a MLL suggests that the trauma had a tangential impact. However, there is difficulty concerning the lumbar region because subcutaneous oedema is not uncommon. Careful dissection can allow definition if the closed soft tissue injury is between the subcutaneous tissue and the muscular fascia (indicating MLL) or in the hypodermis (indicating subcutaneous oedema). It can thus be distinguished from an intramuscular haematoma or haemorrhagic effusion whose mechanisms are less specific. A post-mortem scan could provide other information to make the diagnosis, particularly for polytraumatic deaths, but to our knowledge, there is no such description in the literature.

Table 1 Magnetic resonance classification of Morel-Lavallée lesions by Mellado and Bencardino [10]).

\begin{tabular}{|c|c|c|c|c|c|c|}
\hline & $\frac{\text { Type I }}{\text { Seroma }}$ & $\begin{array}{c}\text { Type II } \\
\text { Subacute } \\
\text { haematoma }\end{array}$ & $\begin{array}{c}\text { Type III } \\
\text { Chronic } \\
\text { organizing } \\
\text { haematoma }\end{array}$ & 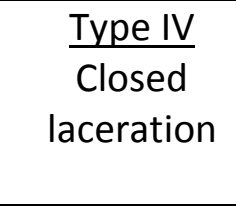 & $\begin{array}{l}\frac{\text { Type V }}{\text { Pseudo- }} \\
\text { nodular }\end{array}$ & $\frac{\text { Type VI }}{\text { Infected }}$ \\
\hline Morphology & Laminar & Oval & Oval & Linear & Round & Variable \\
\hline Capsule & Occasional & Thin & Thick & Absent & Thin/thick & Thick \\
\hline T1 signal & Hypointense & Hyperintense & elntermediate & Hypointense & Variable & Variable \\
\hline T2 signal & Hyperintense & eHyperintense & eHeterogeneou & sHyperintense & eVariable & Variable \\
\hline Enhancement & Absent & Variable & $\begin{array}{l}\text { Internal/ } \\
\text { peripheral }\end{array}$ & Variable & $\begin{array}{l}\text { Internal/ } \\
\text { peripheral }\end{array}$ & $\begin{array}{l}\text { Internal/ } \\
\text { peripheral }\end{array}$ \\
\hline
\end{tabular}




\section{Morel-Lavallée lesion and temporary functional disability}

The functional consequences of MLL remain globally limited. For instance, the average resolution time for MLLs of the knee (any size pooled), assessed by the achievement of full active knee flexion, was 16.3 days in a cohort of football players [11]. Medico-legal evaluation of the functional consequences must consider (i) the pain intensity that may cause functional disability and (ii) the fluid volume of the lesion that may cause joint limitations and on which will also depend (iii) the therapeutic management. If the volume is estimated to be less than $50 \mathrm{~mL}$, the first-line treatment is compression wraps, cryotherapy, non-steroidal anti-inflammatory drugs and physiotherapy $[1,3,5,12-14]$. If the volume is greater than $50 \mathrm{~mL}$, aspiration is fulfilled (with or without injection of sclerosing agents). However, in the event of recurrence despite repeated aspiration, surgical management, most often ambulatory, will be necessary (Ronceray's fasciotomy or endoscopic debridement combined with percutaneous cutaneo-fascial suture) [1,3,5,12-14]. As routinely estimated in France, the duration of this functional disability for daily acts can be quantified on a scale called improperly 'Total Incapacity to Work' ('incapacité totale de travail', ITT) and is therefore generally greater than 8 days and less than 3 months. In French criminal proceedings, ITT is used to assess the functional severity of traumatic injuries and to determine the type of sanction decided by justice. Concerning accidents, an ITT greater than 3 months corresponds to an offense in the French penal system and the offender may be fined or jailed. Thus, knowledge of Morel-Lavallée syndrome is interesting because it differs greatly from a simple bruise and its evolution is generally longer. This condition can lead to longer functional discomfort and therefore a longer ITT.

\section{Morel-Lavallée lesion and permanent aftermath}

Early diagnosis and appropriate care seem to allow an evolution without functional consequence in the majority of cases (overall, permanent disability $=0 \%$ ) $[1,2,9]$. Aesthetic damage may exceptionally be considered in the case of a surgical scar or late management, since displacement and laxity of adjacent tissues are possible $[9,13]$. On the other hand, sclerosis of chronic lesions causes cutaneous immobility (but rarely articular immobility), which is symptomatic for high level athletes $[11,13]$. Thereby, functional consequences will be retained only in the case of surgical care or recurrence and concerning high level athletes 
or patients with a very physical job. The resulting permanent disability is generally less than $8 \%$ according to French reference scales [15].

\section{Conclusion}

The MLL is an infrequent lesion but should be known for medico-legal reports.

It is specifically induced by shearing force with moderate-to-high kinetics in an anatomical area with an underlying fascia. Its functional disability is globally moderate, but a large lesion or recurrences can increase the time of resolution of the disability. Early diagnosis and appropriate care seem to allow an evolution without functional consequence, but these lesions are frequently missed in the initial phase. 


\section{References}

1. Nickerson TP, Zielinski MD, Jenkins DH, Schiller HJ. The Mayo Clinic experience with Morel-Lavallée lesions: Establishment of a practice management guideline. J Trauma Acute Care Surg. 2014;76:493-7.

2. Muneer M, El-Menyar A, Abdelrahman H, Murad MA, Al Harami SM, Mokhtar A, et al. Clinical Presentation and Management of Pelvic Morel-Lavallee Injury in Obese Patients. J Emerg Trauma Shock. 2019;12:40-7.

3. Bonilla-Yoon I, Masih S, Patel DB, White EA, Levine BD, Chow K, et al. The Morel-Lavallée lesion: pathophysiology, clinical presentation, imaging features, and treatment options. Emerg Radiol. 2014;21:35-43.

4. Morel-Lavallée V-A-F. Épanchements traumatiques de sérosité. Arch Générales Médecine Paris. 1853;

5. Liu M, Liu L, Zhou X, Wu L, Wang J, Qi L, et al. A Novel Surgical Technique for treatment of Morel-Lavallée Lesion: Endoscopic debridement combined with percutaneous cutaneofascial suture. Injury. 2018;49:1630-3.

6. Moulin C, Barthélémy I, Emering C, D'Incan M. Syndrome de Morel-Lavallée et cytostéatonécrose : deux complications post-traumatiques simulant une dermohypodermite infectieuse. Ann Dermatol Vénéréologie.

7. Scolaro JA, Chao T, Zamorano DP. The Morel-Lavallée Lesion: Diagnosis and Management. J Am Acad Orthop Surg. 2016;24:667-72.

8. Lungu E, Michaud J, Bureau NJ. US Assessment of Sports-related Hip Injuries. RadioGraphics. 2018;38:867-2526

9. Khodaee M, Deu RS, Mathern S, Bravman JT. Morel-Lavallée Lesion in Sports: Curr Sports Med Rep.2016;15:417-22.

10. Mellado JM, Bencardino JT. Morel-Lavallée Lesion: Review with Emphasis on MR Imaging. Magn Reson Imaging Clin N Am. 2005;13:775-82.

11. Tejwani SG, Cohen SB, Bradley JP. Management of Morel-Lavallee Lesion of the Knee: Twenty-Seven Cases in the National Football League. Am J Sports Med. 2007;35:1162-7.

12. Dawre S, Lamba S, H S, Gupta S, Gupta AK. The Morel-Lavallee lesion: a review and a proposed algorithmic approach. Eur J Plast Surg. 2012;35:489-94.

13. Greenhill D, Haydel C, Rehman S. Management of the Morel-Lavallée Lesion. Orthop Clin North Am. 4142155 2016;47:115-25. 
14. Coulibaly NF, Sankale AA, Sy MH, Kinkpe CVA, Kasse AN, Diouf S, et al. Épanchement de Morel-Lavallée en chirurgie orthopédique (À propos de 19 cas). Ann Chir Plast Esthét.

2011;56:27-32.

15. Anciaux P, Béjui J, Buu-Hoï P, Cantaloube D, Chikhani L, Chodkiewicz J-P, et al. Barème indicatif d'évaluation des taux d'incapacité en droit commun [Internet]. Le concours médical; 2001 [cited 2019 Jun 24]. Available from:

http://www.expertisemedicale.be/upload/documents/documentation/Bareme_indicatif_d_ evaluation.pdf 